\title{
Anion Transport in Sickle Red Blood Cells
}

\author{
CLINTON H. JOINER, ROBERT B. GUNN, AND OTTO FRÖHLICH \\ Departments of Pediatrics and Physiology and Biophysics, and Perinatal Research Institute, University of \\ Cincinnati College of Medicine, Cincinnati, Ohio 45267-0541 [C.H.J.]; Department of Physiology and \\ Biophysics, Emory University, Atlanta, Georgia 30322 [R.B.G., O.F.]; and Department of Pediatrics, University \\ of Alabama at Birmingham, Birmingham, Alabama 35294 [C.H.J.]
}

\begin{abstract}
Anion transport in sickle cells (SS RBC) mediated by the band 3 membrane protein was evaluated by three different measures in both oxygenated and deoxygenated conditions and compared to normal red cells. First, $\mathrm{Cl}^{-}$self-exchange measured as ${ }^{36} \mathrm{Cl}^{-}$efflux at $0^{\circ} \mathrm{C}$ was normal in SS RBC in both $V_{\max }$ and dependence on extracellular $\mathrm{Cl}^{-}$concentration. There was no effect of deoxygenation on either parameter. Second, stilbene-sensitive ${ }^{35} \mathrm{SO}_{4}^{=}: \mathrm{SO}_{4}^{-}$exchange, measured at $37^{\circ} \mathrm{C}$ where morphologic sickling occurred, was also unaffected by deoxygenation and was normal compared to normal red cells. Third, conductive $\mathrm{Cl}^{-}$flux was assessed by measuring the rates of $\mathrm{Cl}^{-}$-limited $\mathrm{K}^{+}$efflux in valinomycin-treated cells at $37^{\circ} \mathrm{C}$. Both the stilbene-sensitive and insensitive components of net $\mathrm{Cl}^{-}$flux were similar in SS RBC and normal red cells, and were unaltered by morphologic sickling. Thus, despite dramatic alterations in cation transport in SS RBC and the demonstration of interaction between band 3 protein and sickle cell, anion transport functions appear to be normal in SS RBC and are unaffected by deoxygenation. These data suggest that the majority of the anion exchangers in SS RBC are functionally normal. (Pediatr Res 28: 587-590, 1990)
\end{abstract}

\section{Abbreviations}

$\mathrm{HbS}$, sickle cell hemoglobin

SS, sickle

AA, normal

HEPES, $N$-2-hydroxyethylpiperazine- $N^{\prime}$-2-ethanesulfonic acid

DIDS, 4, $4^{\prime}$-diisothiocyanostilbene-2, $2^{\prime}$-disulfonate

DNDS, 4,4'-dinitrostilbene-2,2'-disulfonate

$K_{1 / 2}$, concentration at one-half maximal velocity

$\mathrm{RBC}$, red blood cell

Sickle cell anemia is associated with numerous perturbations of the red cell membrane. Oxygenated SS cells exhibit abnormalities in the membrane skeleton $(1,2)$, oxidation of membrane lipid (3) and proteins $(4,5)$, and membrane mechanical properties (6). The activities of the volume-sensitive and $\mathrm{pH}$-sensitive $\mathrm{KCl}$ cotransport system $(7,8)$ and the $\mathrm{Na}^{+} / \mathrm{H}^{+}$exchange mechanism (9) are increased, whereas that of the $\mathrm{Na}^{+} / \mathrm{K}^{+}$pump is apparently reduced in certain populations of SS cells $(10)$. Deoxygenation of SS cells induces additional changes in transbilayer

Received April 9, 1990, accepted August 8, 1990

Correspondence: Clinton H. Joiner, M.D., Ph.D., Associate Professor of Pediatrics, and Physiology and Biophysics, University of Cincinnati College of Medicine, Cincinnati, OH 45267-0541.

Supported in part by USPHS Grants HL 37515 (C.H.J.), HL 28674 (R.B.G.), and GM 31269 (O.F.) lipid dynamics (11-13) and a marked increase in passive monovalent cation permeability (14-16). These diverse membrane abnormalities are believed to play a substantial role in the pathophysiology of the SS cell, affecting membrane deformability $(17,18)$, cellular hydration and volume control $(7,8,19)$, rate of deoxy $\mathrm{HbS}$ polymerization (20), and interactions between red cells and the vascular endothelium $(21,22)$.

A major protein constituent of the red cell membrane is the integral membrane protein known as band 3 from its position on polyacrylamide gels (23). The membrane spanning domain of this protein catalyzes $\mathrm{Cl}^{-} / \mathrm{HCO}_{3}^{-}$exchange, which is important in $\mathrm{CO}_{2}$ transport and rapid equilibration of plasma and cytoplasmic protons (24). Band 3 may also mediate most of the uncoupled, or conductive, movement of $\mathrm{Cl}^{-}$in the red cells $(25$, 26). The cytoplasmic domain of band 3 is an attachment site for the membrane skeleton to the inside surface of the membrane (27). To determine if the chronic and acute perturbations of membrane structure and function exhibited by SS cells also affect anion transport, we measured $\mathrm{Cl}^{-}: \mathrm{Cl}^{-}$exchange at $0^{\circ} \mathrm{C}$, $\mathrm{SO}_{4}^{\overline{-}}: \mathrm{SO}_{4}^{\overline{4}}$ exchange at $37^{\circ} \mathrm{C}$, and conductive $\mathrm{Cl}^{-}$net efflux (as net $\mathrm{K}$ efflux from $\mathrm{K}^{+}$permeabilized cells) in oxygenated and deoxygenated SS cells compared to AA red cells. None of these functional assays of anion transport were different in SS cells compared to AA cells, and none were affected by deoxygenation. A preliminary report of these findings has been presented (28).

\section{MATERIALS AND METHODS}

$R B C$. Blood was drawn from patients homozygous for $\mathrm{HbS}$ and normal subjects by venipuncture, using heparin or EDTA as anticoagulant. Blood was washed three times with the appropriate buffer, and the buffy coat was carefully aspirated after each centrifugation. Cells were generally used the day of venipuncture, but washed cells that were resuspended in a HEPESbuffered solution containing $135 \mathrm{mM} \mathrm{KCl}, 15 \mathrm{mM} \mathrm{NaCl}$ and stored at $10^{\circ} \mathrm{C}$ overnight gave similar results and are also reported.

$\mathrm{Cl}^{-}: \mathrm{Cl}^{-}$exchange. Washed, unfractionated $\mathrm{RBC}$ were suspended in glycylglycine buffered saline $(140 \mathrm{mM} \mathrm{NaCl}, 27 \mathrm{mM}$ glycylglycine, $\mathrm{pH} 7.8$ ) and exposed to humidified air or $\mathrm{N}_{2}$ in a rotary evaporator flask for at least $1 \mathrm{~h}$ at $22^{\circ} \mathrm{C}$. We then used previously published methods to measure the $\mathrm{Cl}^{-}: \mathrm{Cl}^{-}$exchange flux (29). Briefly, cells were loaded with ${ }^{36} \mathrm{Cl}^{-}$, packed by centrifugation at $4^{\circ} \mathrm{C}$ and injected into solutions $\left(\right.$ at $\left.0^{\circ} \mathrm{C}\right)$ with different external $\mathrm{Cl}^{-}$concentrations $\left(\mathrm{Cl}_{0}^{-}=1-150 \mathrm{mM}\right)$ made by mixing glycylglycine buffered saline with a solution containing $25 \mathrm{mM}$ $\mathrm{Na}_{3}$ citrate, $27 \mathrm{mM}$ glycylglycine, $200 \mathrm{mM}$ sucrose, pH 7.8. These solutions with different $\mathrm{Cl}_{0}^{-}$all have equal osmolalities and equal ionic strengths (29). The time course of appearance of ${ }^{36} \mathrm{Cl}^{-}$in the medium, corrected for hemolysis, was followed and used together with the chloride content of duplicate cell samples to calculate the flux [mmol chloride $\left.(\mathrm{kg} \mathrm{Hb})^{-1} \cdot \mathrm{min}^{-1}\right]$. These flux values were analyzed using nonlinear least squares analysis 
assuming Michaelis-Menten kinetics to calculate a $\mathrm{V}_{\max }$ and $\mathrm{Cl}_{0}^{-}$at $1 / 2$ maximal velocity $\left(\mathrm{K}_{1 / 2}\right)(29)$.

${ }^{35} \mathrm{SO}_{4}^{=}: \mathrm{SO}_{4}^{-}$exchange. $\mathrm{SO}_{4}^{=}$exchange was measured as ${ }^{35} \mathrm{SO}_{4}^{=}$ uptake in cells suspended in $140 \mathrm{mM} \mathrm{NaCl}, 20 \mathrm{mM}$ HEPES (pH 7.4 at $37^{\circ} \mathrm{C}$ ), $5 \mathrm{mM} \mathrm{Na}_{2} \mathrm{SO}_{4}, 10 \mathrm{mM}$ glucose. After $1 \mathrm{~h}$ preincubation at $37^{\circ} \mathrm{C}$ to equilibrate nonradioactive $\mathrm{SO}_{4}^{\bar{y}}$, cells were gassed with air or $\mathrm{N}_{2}$ for 15 min using vacuum and gas flushing, and then ${ }^{35} \mathrm{SO}_{4}^{=}(5 \mu \mathrm{Ci} / \mathrm{mL} ; 185 \mathrm{kBq} / \mathrm{mL})$ was added. Samples were taken at 4 and $19 \mathrm{~min}$ for control and 4 and $64 \mathrm{~min}$ for cells treated with $45 \mu \mathrm{M}$ DIDS and spun through dibutyl phthalate, as described previously for cellular cation determinations (30). $\mathrm{SO}_{4}^{=}$uptake was calculated from medium sp act measured in each suspension and normalized to sample $\mathrm{Hb}$.

Although ${ }^{35} \mathrm{SO}_{4}^{=}$uptake in the presence of DIDS was subtracted from total uptake to calculate the DIDS-sensitive component, the DIDS-insensitive component was too small and variable to analyze quantitatively. A portion of DIDS-insensitive ${ }^{35} \mathrm{SO}_{4}^{=}$uptake was neither directly proportional to ${ }^{35} \mathrm{SO}_{4}^{-} \mathrm{sp}$ act nor linearly dependent on uptake times. These nonspecific, non-band 3 mediated, DIDS-insensitive $\mathrm{SO}_{4}^{-}$influx rates are not reported.

Table 1. Effect of deoxygenation on the kinetics of $\mathrm{Cl}^{-}: \mathrm{Cl}^{-}$ exchange at $0^{\circ} \mathrm{C}$ in $S S$ and $A A$ red cells*

\begin{tabular}{cccccc}
\hline & \multicolumn{3}{c}{$\mathrm{SS}$} & & \multicolumn{2}{c}{$\mathrm{AA}$} \\
\cline { 2 - 3 } \cline { 5 - 6 } & \multicolumn{1}{c}{$\mathrm{O}_{2}$} & $\mathrm{~N}_{2}$ & & $\mathrm{O}_{2}$ & $\mathrm{~N}_{2}$ \\
\hline $\mathrm{V}_{\max }[\mathrm{mmol} \cdot$ & $710(40)$ & $610(20)$ & & $730(50)$ & $880(60)$ \\
$\left.(\mathrm{kgHb})^{-1} \cdot \mathrm{min}^{-1}\right]$ & $660(50)$ & $710(70)$ & & $790(30)$ & $950(30)$ \\
$\mathrm{K}_{1 / 2}$ for Cl & $(\mathrm{mM})$ & $4.5(0.1)$ & $2.1(0.2)$ & $3.5(0.8)$ & $3.7(0.7)$ \\
& $3.3(0.5)$ & $2.1(0.6)$ & $2.1(0.3)$ & $3.0(0.3)$ \\
\hline
\end{tabular}

* In each experiment, ${ }^{36} \mathrm{Cl}^{-}$efflux was measured at five to eight different $\mathrm{Cl}_{0}^{-}$concentrations, and the curve fitted by nonlinear regression analysis to a rectangular hyperbola to calculate $\mathrm{V}_{\max }$ and apparent affinity for $\mathrm{Cl}_{0}^{-}\left(\mathrm{K}_{1 / 2}\right)$. The data represent the values in oxy and deoxy AA and SS $\mathrm{RBC}$ in eight separate experiments. Numbers in parentheses are standard errors of estimate of the given parameter derived from the regression analysis of the fluxes for that experiment. Although these standard errors are small, in our experience $\mathrm{K}_{1 / 2}$ values vary from 2 to $4 \mathrm{mM}$ in experiments from normal $\mathrm{RBC}$, even with the same donor (29). Thus, the standard errors given are more reflective of the correlation coefficient of the regression curve for a given experiment than the variance among experiments or individuals. Formal statistical analysis, therefore, is not warranted, and $\mathrm{K}_{1 / 2}$ values between 2 and $5 \mathrm{mM}$ are considered normal. The values for $\mathrm{V}_{\max }$ and $\mathrm{K}_{1 / 2}$ for a given experiment are in corresponding positions in the table.

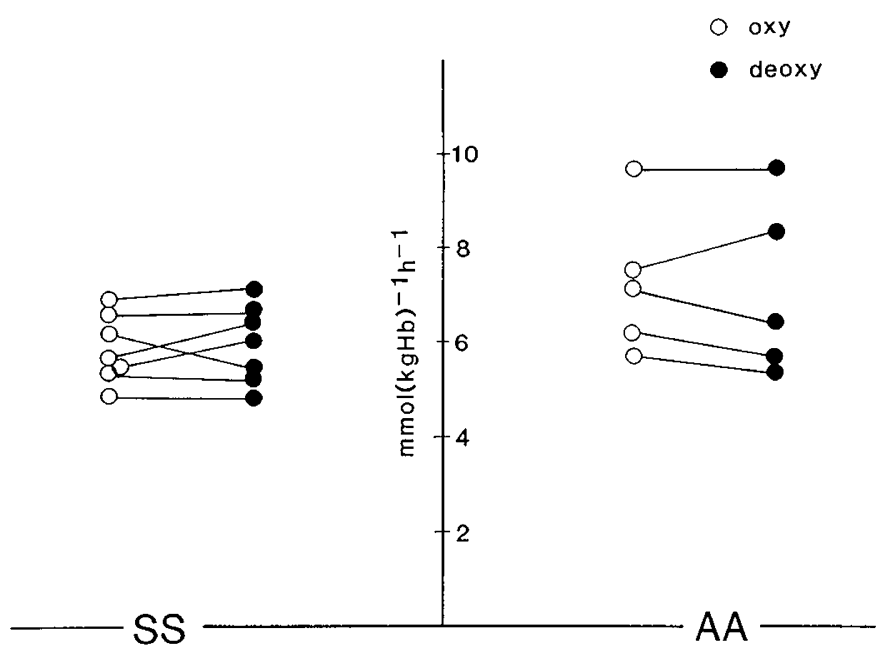

Fig. 1. Stilbene sensitive $\mathrm{SO}_{4}^{\bar{z}}$ uptake in $\mathrm{SS}$ and $\mathrm{AA}$ RBC. Cells were first pre-equilibrated with $5 \mathrm{mM} \mathrm{SO}_{4}^{\overline{-}}$, then to half of the cells DIDS was added $(45 \mu \mathrm{M})$. Cells were subsequently equilibrated with air or $\mathrm{N}_{2}$ and ${ }^{35} \mathrm{SO}_{4}=$ added. Samples were taken and processed as described for assay of radioactivity and $\mathrm{Hb}$.
Table 2. Effect of deoxygenation on anion transport functions at $37^{\circ} \mathrm{C}$ in $S S$ and $A A$ red cells

\begin{tabular}{ccccccccc}
\hline & \multicolumn{3}{c}{$\mathrm{SS}$} & \multicolumn{3}{c}{$\mathrm{AA}$} \\
\cline { 2 - 8 } \cline { 3 - 7 } & $\mathrm{O}_{2}$ & $\mathrm{~N}_{2}$ & $n$ & $\mathrm{O}_{2}$ & $\mathrm{~N}_{2}$ & $n$ \\
\hline
\end{tabular}

DIDS-sensitive

$\mathrm{SO}_{4}^{=}: \mathrm{SO}_{4}^{=}$ex-

change*

$\mathrm{Cl}^{-}$-limited $\mathrm{K}$ ef-

flux in valino-

mycin-treated

cells $\dagger$

Total

$21.4(5.2) \quad 24.3(7.2) \quad 4 \quad 24.8(6.0) \quad 24.4(6.0) \quad 3$

$\begin{array}{llllll}\text { DNDS-insensi- } \quad 4.5(0.9) & 5.2(1.4) & 4 & 6.0(1.2) & 5.5(0.5) & 3\end{array}$

tive

DNDS-sensitive $16.9(5.2) \quad 19.0(8.1) \quad 18.7(4.7) \quad 18.9(5.6)$

${ }^{*}$ mmol $(\mathrm{kg} \mathrm{Hb})^{-1} \cdot \mathrm{h}^{-1}$. Data are means $(\mathrm{SD})$ of the paired $\mathrm{O}_{2} / \mathrm{N}_{2}$ determinations depicted in Figure 1.

$\dagger \mathrm{mmol}(\mathrm{kg} \mathrm{Hb})^{-1} \cdot \mathrm{min}^{-1}$. Data are means $(\mathrm{SD})$ of the paired $\mathrm{O}_{2} / \mathrm{N}_{2}$ determinations depicted in Figure 2. DNDS-sensitive flux was calculated for each $\mathrm{O}_{2} / \mathrm{N}_{2}$ pair and the results averaged.

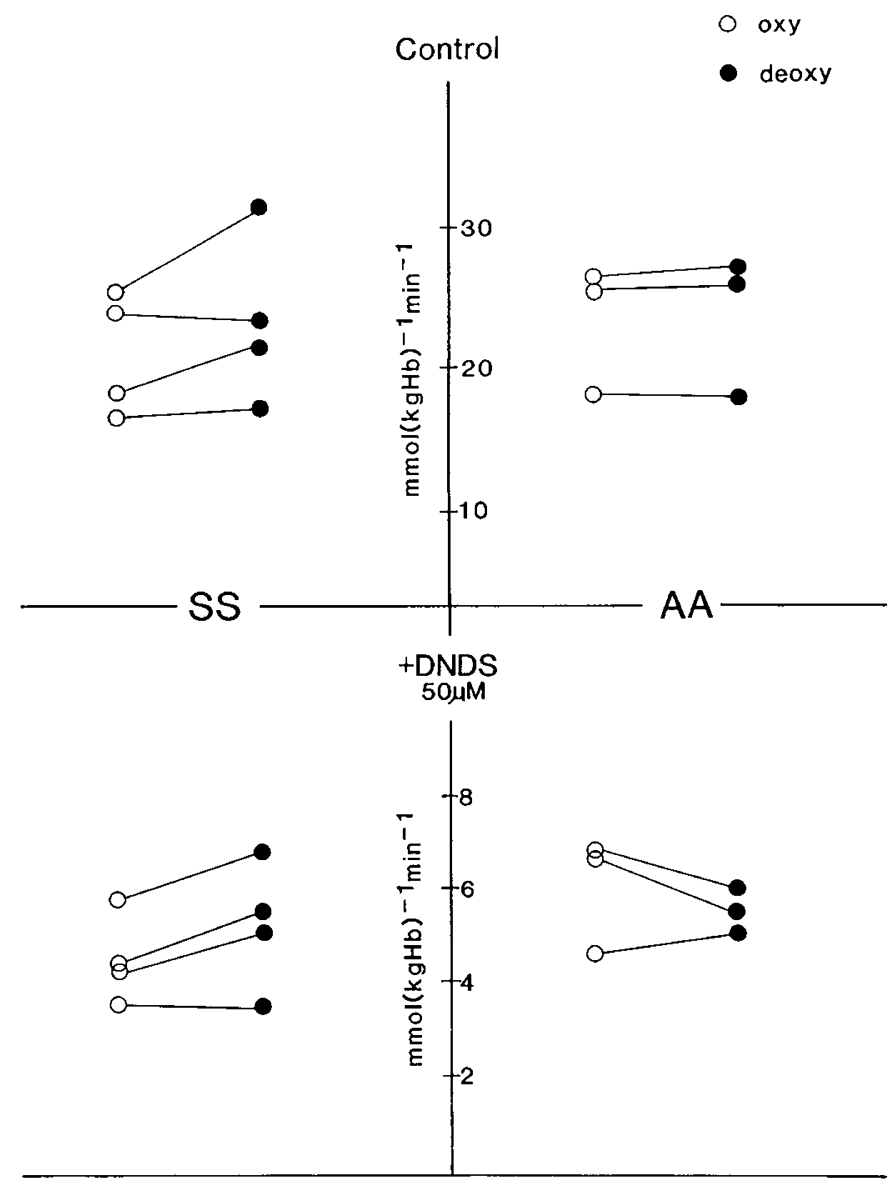

Fig. 2. Chloride-limited $\mathrm{K}^{+}$efflux in valinomycin-treated $\mathrm{SS}$ and AA RBC. $\mathrm{K}$ efflux was measured as described in Materials and Methods. Each data point represents the mean of three flux determinations. Standard error bars for each data point are omitted for the sake of clarity; the average coefficient of variation of triplicate fluxes for these experiments was $7 \%$. Oxy and deoxy pairs are connected.

Conductive $\mathrm{Cl}^{-}$permeability. Conductive $\mathrm{Cl}^{-}$permeability was measured as the rate of $\mathrm{K}^{+}$loss in valinomycin-treated cells, in which $\mathrm{K}$ permeability exceeds $\mathrm{Cl}^{-}$permeability and the latter therefore limits the rate of net $\mathrm{KCl}$ efflux (26). Cells were washed in HEPES buffered saline $(140 \mathrm{mM} \mathrm{NaCl}, 20 \mathrm{mM}$ HEPES, $\mathrm{pH}$ 7.4) and resuspended at $2^{\circ} \mathrm{C}$ hematocrit in HEPES buffered saline 
containing $4 \mathrm{mM} \mathrm{KCl}$. After warming to $37^{\circ} \mathrm{C}$ and equilibration with air or $\mathrm{N}_{2}$, valinomycin was added to give a final nominal concentration of $5 \mu \mathrm{M}(31)$. DNDS, a reversible stilbene inhibitor of band 3 , when present, was added $(50 \mu \mathrm{M})$ before valinomycin. Triplicate samples were taken at four or five time points over 6$10 \mathrm{~min}$ for centrifugation through phthalate. Cellular $\mathrm{K}^{+}$was measured by atomic absorption spectrophotometry, and normalized to sample $\mathrm{Hb}$. Flux rates were calculated from least square regression slopes of cellular $\mathrm{K}^{+}$versus time.

\section{RESULTS}

$\mathrm{Cl}^{-}: \mathrm{Cl}^{-}$exchange in deoxygenated $\mathrm{SS}$ cells: The kinetic parameters for $\mathrm{Cl}^{-}: \mathrm{Cl}^{-}$exchange obtained from the analysis of 118 separate flux measurements are summarized in Table 1. Values of $\mathrm{K}_{1 / 2}$ for external $\mathrm{Cl}^{-}$fell within the normal range (2-5 mM) for both SS and AA cells, regardless of oxygenation state. The degree of variation in $\mathrm{K}_{1 / 2}$ among these experiments is normally seen among different experimental determinations, even with RBC from the same donor (29). Similarly, there was no substantial difference in $\mathrm{V}_{\max }$ values comparing $\mathrm{AA}$ and SS cells or oxygenated versus deoxygenated cells. The $\mathrm{V}_{\max }$ determinations in oxygenated AA and SS cells fall into the range of values found in independent experiments to be 600 to $1100 \mathrm{mmol}(\mathrm{kg} \mathrm{Hb})^{-1}$. $\min ^{-1}(32)$.

$\mathrm{SO}_{4}^{\overline{ }}: \mathrm{SO}_{4}^{\overline{\bar{y}}}$ exchange in $\mathrm{AA}$ cells. Because morphologic sickling is inhibited by the low temperatures required for measurement of $\mathrm{Cl}^{-}: \mathrm{Cl}^{-}$exchange (33), $\mathrm{SO}_{4}^{-}: \mathrm{SO}_{4}^{-}$exchange was assayed at $37^{\circ} \mathrm{C}$ in oxygenated and deoxygenated SS cells under conditions where morphologic sickling occurred. These data are depicted in Figure 1 for both SS and AA erythrocytes. There was no consistent effect of deoxygenation on anion exchange in either cell type. Mean values in oxygenated and deoxygenated cells were virtually identical in both SS and AA cells (Table 2), and the differences in $\mathrm{SO}_{4}^{\overline{ }}: \mathrm{SO}_{\overline{4}}^{\overline{\bar{y}}}$ exchange between oxygenated $\mathrm{AA}$ and $\mathrm{SS}$ cells were not statistically significant by $t$ test. Under these conditions, DIDS inhibited 97 to $99 \%$ of $\mathrm{SO}_{4}^{-}$exchange, with no effect of deoxygenation or $\mathrm{Hb}$ type on inhibition (34).

Conductive anion permeability in $S S$ cells. $\mathrm{Cl}^{-}$-limited $\mathrm{K}^{+}$ efflux in valinomycin-treated cells was used to assay the conductive anion permeability. Cells were deoxygenated (or exposed to air), then valinomycin was added to initiate the $\mathrm{K}^{+}$efflux in the presence or absence of $50 \mu \mathrm{M}$ DNDS. This concentration of DNDS was insufficient to affect deoxygenation-induced cation movements, with $500 \mu \mathrm{M}$ DNDS inhibiting these cation fluxes by only $51 \%( \pm 11 \mathrm{SEM}, n=5)$ (34). Thus, under the conditions of the $\mathrm{Cl}^{-}$-limited $\mathrm{K}^{+}$efflux experiments, the deoxygenationinduced cation pathway was not inhibited by DNDS. Figure 2 shows the effect of deoxygenation on total $\mathrm{Cl}^{-}$-limited $\mathrm{K}$ efflux and the DNDS-sensitive component in valinomycin-treated cells. In Table 2, the average values of these fluxes are given, along with the DNDS-sensitive component calculated from them. As with anion exchange, there was no consistent effect of deoxygenation on any of these components of conductive anion movement in AA or SS cells. Net anion movements in SS and AA cells were not substantially different.

\section{DISCUSSION}

Our study has characterized anion transport in SS red cells with respect to the kinetic parameters of $\mathrm{Cl}^{-}$exchange at $0^{\circ} \mathrm{C}$, sulfate exchange at $37^{\circ} \mathrm{C}$, conductive $\mathrm{Cl}^{-}$movements at $37^{\circ} \mathrm{C}$, and the effects of deoxygenation. No substantial differences were found between SS and AA cells in oxygenated, unfractionated cells. Our study, therefore, did not confirm the preliminary reports that conductive $\mathrm{Cl}^{-}$permeability (estimated from membrane potential measurements) was either increased (35) or decreased (36) in SS cells compared to AA cells, or that $\mathrm{SO}_{4}^{-}$ exchange flux was increased by $30 \%$ in SS cells (35). Our finding of normal anion transport function in SS cells suggests that the anion exchanger is normal despite the membrane abnormalities described in oxygenated SS cells-increased $\mathrm{Hb}$ binding to the membrane $(37,38)$, lipid and sulfhydryl oxidation $(3-5)$, and abnormal cytoskeletal interactions $(1,2)$-and is unaffected by the processes that produce these pathologic changes. Because these experiments used unfractionated red cell populations, subtle abnormalities in anion transport in a small subpopulation of SS cells might have gone undetected. We did not explore this possibility further.

We found no effect of sickling on either the exchange or conductive functions of the anion transport mechanism in SS cells as assessed by $\mathrm{SO}_{4}^{\bar{y}}$ influx and DNDS-sensitive, $\mathrm{Cl}^{-}$-limited net $\mathrm{K}^{+}$efflux. This indicates that the majority of anion exchange molecules are not affected by deoxygenation of $\mathrm{HbS}$. The lack of effect of deoxygenation on DIDS-sensitive $\mathrm{SO}_{4}^{=}$efflux, recently reported in an abstract by Clark and Rossi (39), supports this interpretation. The experimental techniques used in our study, as well as that of Clark and Rossi (39), would not permit the detection of changes in anion transport localized to the membrane spicules of deoxygenated SS cells, inasmuch as only 1 to $3 \%$ of the membrane surface is involved in spicule formation (11). Thus, no inferences can be made about the effect on local anion transport function of those deoxygenation-induced processes that are thought to be localized to membrane spicules, such as uncoupling of the lipid bilayer from the cytoskeleton and changes in lipid dynamics $(11,12)$.

The question of whether $\mathrm{Cl}^{-}$may transverse the deoxygenation-induced pathway that mediates the increased cation permeability of deoxygenated SS cells is of interest, particularly in view of the observation that DIDS inhibits these cation movements by $80-90 \%$ (34). Our finding that deoxygenation was without effect on DNDS-insensitive $\mathrm{Cl}^{-}$-limited $\mathrm{K}$ efflux indicates clearly that $\mathrm{Cl}^{-}$permeability is not increased by deoxygenation proportionally to the increase in cation permeability, i.e. $\mathrm{Cl}^{-}$permeability is clearly not increased 3 - to 10 -fold as is cation permeability. On the other hand, a deoxygenation-induced $\mathrm{Cl}^{-}$flux equivalent in magnitude to the cation flux $[0.3-0.5 \mathrm{mmol}(\mathrm{kg}$ $\mathrm{Hb})^{-1} \cdot \mathrm{min}^{-1}$ ] would not be detectable on top of the large baseline net $\mathrm{Cl}^{-}$flux of 4-5 mmol $(\mathrm{kg} \mathrm{Hb})^{-1} \cdot \mathrm{min}^{-1}$ (see Table 2). Clark and Rossi (39) have reported that DIDS-insensitive $\mathrm{SO}_{4}^{-}$efflux was unchanged by deoxygenation of SS cells but those experiments were performed at 50- $\mu \mathrm{M}$ DIDS concentrations, where the deoxygenation-induced cation pathway is substantially inhibited $(34,39)$. Considered together, the high basal $\mathrm{Cl}^{-}$permeability of the red cell relative to cations, the even higher anion exchange rates, and the sensitivity of the deoxygenation-induced pathway to DIDS represent substantial experimental impediments to assessing the capacity of the deoxygenation-induced membrane lesion to mediate $\mathrm{Cl}^{-}$movements. Thus, although it is clear from our experiments that anion transport via band 3 in SS red cells is not changed by deoxygenation, it will require a different experimental approach to determine if anions can traverse the deoxygenation-induced pathway that increases cation permeability in these cells.

Acknowledgments. The authors thank Dr. Iris Buchannnan, Department of Pediatrics, Emory University, and Grady Memorial Hospital, for obtaining sickle blood samples. We thank Gary Glick and Arlene Dew for technical assistance and Mary Brunner for help in preparing the manuscript.

\section{REFERENCES}

1. Lux SE, John KM, Karnovsky MJ 1976 Irreversible deformation of the spectrin-action lattice in irreversibly sickled cells. J Clin Invest 58:955-963

2. Platt OS, Falcone JF, Lux SE 1985 Molecular defect in the sickle erythrocyte skeleton: abnormal spectrin binding to sickle inside-out vesicles. J Clin Invest 75:266-271

3. Jain SK, Shohet SB 1984 A novel phospholipid in irreversibly sickled cells: evidence for in vivo peroxidative membrane damage in sickle cell disease. Blood 63:362-367 
4. Rank BH, Carlsson J, Hebbel RP 1985 Abnormal redox status of membraneprotein thiols in sickle erythrocytes. J Clin Invest 75:1531-1537

5. Schwartz RS, Rybicki AC, Heath RH, Lubin BH 1987 Protein 4.1 in sickle erythrocytes: evidence for oxidative damage. J Biol Chem 262:15666-15672

6. Evans EA, Mohandas N 1987 Membrane-associated sickle hemoglobin: a major determinant of sickle erythrocyte rigidity. Blood 70:1443-1449

7. Brugnara C, Bunn HF, Tosteson DC 1986 Regulation of erythrocyte cation and water content in sickle cell anemia. Science 232:288-290

8. Canessa M, Spalvins A, Nagel RL 1986 Volume-dependent and NEM-stimulated $\mathrm{KCl}$ transport is elevated in oxygenated SS, SC, and $\mathrm{CC}$ human red cells. FEBS Lett 200:197-205

9. Canessa M, Spalvins A, Morgan K, Bak M, Fabry ME, Nagel RL 1989 Na+/ $\mathrm{H}+$ exchange is increased in $\mathrm{HbSS}$ red cells: age dependence and interindividual differences. J Physiol (Lond) 92:39a(abstr)

10. Clark MR, Morrison CE, Shohet SB 1979 Monovalent cation transport in irreversibly sickled cells. J Clin Invest 62:329-337

11. Franck PFH, Bevers EM, Lubin BH, Comfurius P, Chiu DT-Y, Op den Kamp JAF, Zwall RFA, Van Deenan LLM, Roelofsen B 1985 Uncoupling of the membrane skeleton from the lipid bilayer. The cause of accelerated phospholipid flip-flop leading to an enhanced procoagulant activity of sickle cells $\mathrm{J}$ Clin Invest 75:183-190

12. Choe H-R, Schlegel RA, Rubin E, Willamson P, Westerman MP 1986 Alteration of red cell membrane organization in sickle cell anemia. Br J Haemato 63:761-773

13. Mohandas N, Rossi ME, Ballas SK, Shohet SB 1985 The structural organization of skeletal proteins influences lipid translocation across erythrocyte membrane. J Biol Chem 260:14264-14268

14. Berkowitz LR, Orringer EP 1985 Passive sodium and potassium movements in sickle erythrocytes. Am J Physiol 249:C208-C214

15. Mohandas N, Rossi MR, Clark MR 1986 Association between morphologic distortion of sickle cells and deoxygenation-induced cation permeability increase. Blood 68:450-454

16. Joiner CH, Dew A, Ge DL 1988 Deoxygenation-induced cation fluxes in sickle cells: relationship between net potassium efflux and net sodium influx. Blood Cells 13:339-354

17. Clark MR, Mohandas N, Shohet SB 1980 Deformability of oxygenated irreversibly sickled cells. J Clin Invest 65:189-196

18. Kaul DK, Fabry ME, Windish P, Baez S, Nagel RL 1983 Erythrocytes in sickle cell anemia are heterogeneous in their rheological and hemodynamic characteristics. J Clin Invest 72:22-3

19. Joiner $\mathrm{CH}$, Platt OS, Lux SE 1986 Cation depletion by the sodium pump in red cells with pathologic cation leaks. Sickle cells and xerocytes. J Clin Invest 78:1487-1496

20. Eaton WA, Hofrichter J 1987 Hemoglobin S gelation and sickle cell disease. Blood 70:1245-1267

21. Hebbel RP, Boogaerts MAB, Eaton JW, Steinbert MH 1980 Erythrocyte adherence to endothelium in sickle cell anemia. New Engl $J$ Med 302:992995
22. Schwartz RS, Tanaka Y, Fidler IH, Chiu DT-Y, Lubin B, Schroit AJ 1985 Increased adherence of sickled and phosphatidylserine enriched human erythrocytes to cultured human peripheral blood monocytes. $\mathrm{J}$ Clin Invest 75:1965-197

23. Cabatchik $\mathrm{Zl}$, Rothstein A 1974 Membrane proteins related to anion permeability of human red blood cells: I. Localization of disulfonic stilbene binding sites in proteins involved in permeation. J Membr Biol 15:207-226

24. Knauf PA 1979 Erythrocyte anion exchange and the Band 3 protein: transport kinetics and molecular structure. Curr Top Membr Transp 12:249-365

25. Knauf PA, Law FY, Marchant PJ 1983 Relationship between net chloride flow across the human erythrocyte membrane to the anion exchange mechanism. J Gen Physiol 81:95-126

26. Fröhlich O 1984 Relative contributions of slippage and tunneling mechanisms to anion net efflux from human erythrocytes. J Gen Physiol 84:877-893

27. Bennett V, Stenbuck PJ 1989 Association between ankyrin and the cytoplasmic domain of Band 3 isolated from the human erythrocyte membrane. $J$ Biol Chem 255:6424-6432

28. Joiner CH, Fröhlich O, Gunn RB 1989 Anion transport in sickle red cells Blood 74 (suppl 1):260a(abstr)

29. Gunn RB, Fröhlich O 1979 Asymmetry in the mechanism for anion exchange in human red blood cell membranes: evidence for reciprocating sites that react with one transported ion at a time. J Gen Physiol 74:351-374

30. Gunn RB, Tosteson DC 1971 The effect of 2,4,6-trinitro-m-cresol on cation and anion transport in sheep red blood cells. J Gen Physiol 57:593-609

31. Hunter MJ 1974 The use of lipid bilayers as cell membrane models: an experimental test using the ionophore, valinomycin. In: Callingham BA (ed) Drugs and Transport Processes. MacMillan, London, pp 227-240

32. Fröhlich O, Gunn RB 1981 Binding of cis and trans isomers of 4,4'-dinitrostilbene-2,2'-disulfonate (DNDS) to the erythrocyte anion transporter. In: Hollán SR, Gárdos G, Sarkadi B (eds) Advances in Physiological Sciences, Vol 6. Genetics, Structure and Function of Blood Cells. Akadémi Kiadó, Budapest, pp 275-280

33. Asakura T, Mayberry J 1984 Relationship between morphologic characteristics of sickle cells and methods of deoxygenation. J Lab Clin Med 104:987-994

34. Joiner CH 1990 Deoxygenation-induced cation fluxes in sickle cells: II. Inhibition by stilbene disulfonates. Blood 76:212-218

35. Hoffman JF 1979 Membrane permeability and volume control by human red blood cells. In: Rosa J, Beuzard Y, Hercules J (eds) Development of Therapeutic Agents for Sickle Cell Disease. Elsevier/North Holland, Amsterdam, pp $3-13$

36. Bitterman P, Hoffman JF 1975 Altered chloride transport in red blood cells from patients with hemolytic anemia. Fed Proc 34:328(abstr)

37. Fischer S, Nagel RL, Bookchin RM, Roth Jr EF, Tellez-Nagel I 1975 The binding of hemoglobin to membranes of normal and sickle erythrocytes. Biochim Biophys Acta 375:422-433

38. Shaklai N, Sharma US, Ranney HM 1987 Interaction of sickle cell hemoglobin with erythrocyte membranes. Proc Natl Acad Sci (USA) 78:65-68

39. Clark MR, Rossi ME 1989 Cation selective leak in acutely deoxygenated sickle cells. Blood 74(supp 1):308a(abstr) 